\title{
Control of Annual Grasses and Revegetation in Ponderosa Pine Woodlands
}

\author{
M. DALE CHRISTENSEN, JAMES A. YOUNG, AND \\ RAYMOND A. EVANS
}

Highlight: Application of $1.12 \mathrm{~kg} / \mathrm{ha}$ of the herbicide atrazine sufficiently controlled medusahead or downy brome to permit establishment of perennial wheatgrass in ponderosa pine woodlands previously burned in wildfires. Fall application of atrazine greatly improved survival of ponderosa pine or bitterbrush seedlings transplanted to plots the following spring. Bitterbrush seedlings established naturally in areas treated with atrazine. Apparently the herbicide treatment created a desirable habitat for seed caching by rodents, along with reduction of competition from annual grasses. Higher rates of atrazine controlled most herbaceous vegetation and resulted in greater growth of ponderosa pine seedlings. Failure to establish perennial grasses resulted in reinvasion by annual grasses.

Our purpose was to control annual grasses and permit establishment of desirable perennial grasses, browse species, and/or conifer transplants in burned woodlands.

Small roadside firc arcas in ponderosa pine (Pinus ponderosa) woodlands often become dominated by alien annual-grass communities. These annual-grass communities often become chronic ecologic sores, where highly inflammable fuel accumulates, contributing to repeated burning and burning of larger areas. The cycle should be prevented by immediate seeding of the burned area to perennials that will prevent dominance by the annual grasses. However, once the annuals are established, competition must be reduced before desirable perennial grasses, browse species, and/or trees can be established. On sites marginal for conifers, a combination of all three is often desirable.

\section{Methods}

\section{Experimental Locations}

Studies were conducted at two locations in Modoc National Forest in northeastern California. Both sites, Adin Pass and Baggett Gulch, are located on Adin Mountain Range between Adin and Canby, Calif., and both were burned in the same large wildfire. The sites have contrasting soils, aspect, pre-burn vegetation, and annual-grass communities.

The Adin Pass site is a steep south-facing slope with a very heavy vertisol-clay soil overlying ash beds. The clay soil supported an open ponderosa pine/western juniper (Juniperus occidentalis) woodland, with a few trees of California blackoak (Quercus kelloggii) and Douglas fir (Pseudotsuga menziesii). Jeffrey pine (Pinus jeffreyi) occurs sympatrically with ponderosa pine. On adjacent unburned areas, the understory is composed of low sagebrush (Artemisia arbuscula) and bitterbrush (Purshia tridentata). The herbaceous vegetation is dominated by Sandberg bluegrass (Poa secunda), in association with a host of native broadleaf species. After the burn,

\footnotetext{
The authors are research representative, CIBA-GEIGY Cor poration, Agricultural Division, Greensboro, North Carolina; and range scientists, Agricultural Research Service, U.S. Department of Agriculture, Renewable Resource Center, University of Nevada, Reno.

The study is a cooperative investigation of CIBA-GEIGY Corporation, Agr. Res. Serv., U.S. Dep. Agr., and the Agricultural Experiment Station, Univ. of Nevada, Reno. (Journal Series Number 240.)

Manuscript received April 26, 1973.
}

medusahead (Taeniatherum asperum) invaded to the virtual exclusion of other species.

The second site, Baggett Gulch, is located on a north-facing slope with a silt-loam soil highly influenced by ash. This site supported a relatively dense ponderosa pine stand before burning. Under the pine canopy, prostrate ceanothus (Ceanothus prostratus) was the dominant shrub. Small parks in the pine stands were occupied by big sagebrush (Artemisia tridentata). Columbia needlegrass (Stipa columbiana) and pine bluegrass (Poa scabrella) dominated the herbaceous vegetation.

After burning, this site was invaded by downy brome (Bromus tectorum). Restriction of medusahead to clay soils is typical of this area (Young and Evans, 1970). This site was planted with ponderosa pine seedlings after the initial salvage logging. Apparently, annual-grass competition and browsing damage have reduced survival and growth of these trees.

\section{Herbicide Treatments}

Herbicides were applied at Adin Pass in October, 1966, in 280 liters of water per hectare. In 1967 and 1968 at Adin Pass, and in 1968 and 1969 at Baggett Gulch, we applied the herbicides in water with a low volume of $93.51 /$ ha. At both locations in all years, treatments were applied to $6-$ by $6-\mathrm{m}$ plots arranged in a randomized-block design with four replications, except at Baggett Gulch, where three replications were used.

Adin Pass - We applied atrazine (2-chloro-4-(ethylamino)-6(isopropylamino)-s-triazine) at $0.56,1.12,1.68$, and 2.24 $\mathrm{kg} / \mathrm{ha}$ in October, 1966. Annual grasses had not germinated, and the soil surface was dry. In October, 1967 we repeated all rates of atrazine except $0.56 \mathrm{~kg} / \mathrm{ha}$, on separate areas. In 1968 , atrazine and simazine (2-chloro-4,6-bis(ethylamino)-s-triazine) was applied at the same rates used in 1967.

Baggett Gulch - We applied 1.12, 2.24, 4.48, and 8.96 $\mathrm{kg} / \mathrm{ha}$ of atrazine on separate plots in October, 1968, and May, 1969.

\section{Seeding and Planting}

Areas treated with herbicides at Adin Pass in 1966 and 1967 were seeded the fall after the treatment by handfurrowing and drilling in the bottom of furrows with intermediate wheatgrass (Agropyron intermedium var. 'Amur'.). Areas that received the 1968 herbicide treatments were not seeded.

In the early spring of each year, plots that had been sprayed with herbicide the previous fall and control plots were planted with 2-year-old, nursery-grown ponderosa pine seedlings. The seedlings, grown from seed collected locally, were planted with $1-\mathrm{m}$ spaces between trees. Six bitterbrush seedlings per plot were planted along with the pine seedlings. The bitterbrush seedlings were 10 to $15 \mathrm{~cm}$ tall when transplanted.

The experimental plots at Baggett Gulch were not seeded to grass or planted with bitterbrush. Pine seedlings were transplanted in the spring of 1969 to plots that had been sprayed with herbicide in October, 1968, and to plots that had been sprayed soon after planting.

\section{Sampling}

We annually clipped $\mathrm{m}^{2}$-plots in each treatment at Adin 
Table 1. Herbage yield ( $\mathrm{kg} / \mathrm{ha})^{\mathrm{a}}$ of medusahead, perennial grasses, and forbs during fallow year at Adin Pass. Mean production for fallow years 1967 through 1969 , except for the atrazine rate of $0.56 \mathrm{~kg} / \mathrm{ha}$, which is for 1967 only.

\begin{tabular}{lcccc}
\hline \hline & \multicolumn{4}{c}{ Herbage yield } \\
\cline { 2 - 5 } $\begin{array}{c}\text { Atrazine } \\
(\mathrm{kg} / \mathrm{ha})\end{array}$ & Medusahead & $\begin{array}{c}\text { Perennial } \\
\text { grasses }\end{array}$ & Forbs $^{\mathrm{d}}$ & Total \\
\hline Control & $450 \mathrm{a}$ & 20 & $50 \mathrm{~b}$ & $520 \mathrm{a}$ \\
0.56 & $160 \mathrm{~b}$ & 20 & $70 \mathrm{~b}$ & $250 \mathrm{~b}$ \\
1.12 & $0 \mathrm{c}$ & 30 & $140 \mathrm{a}$ & $170 \mathrm{c}$ \\
1.68 & $0 \mathrm{c}$ & 10 & $60 \mathrm{~b}$ & $70 \mathrm{~d}$ \\
2.24 & $0 \mathrm{c}$ & 10 & $60 \mathrm{~b}$ & $70 \mathrm{~d}$ \\
\hline
\end{tabular}

ane lb/acre equals $1.12 \mathrm{~kg} / \mathrm{ha}$.

$b_{\text {Means followed by the same letter are not significantly different at }}$ the 0.05 level of probability as determined by Duncan's multiple range test. All comparisons are made vertically.

${ }^{c}$ No signiticant differences existed among yields of perennial grasses.

$\mathrm{d}_{\text {Forbs growing on atrazine-treated areas are primarily bindweed }}$ (Convolvulus polymorphus) and turkey mullein (Eremocarpus setigerus).

Pass to determine the influence of the herbicide treatment on herbage production. Step-point sampling (Evans and Love, 1957) was done each year at both locations. The number and height of surviving pine and bitterbrush seedlings were determined annually.

\section{Adin Pass}

\section{Results}

Responses of annual-grass communities to application of atrazine can be predicted with a high level of precision (Evans et al., 1969). Plots sprayed with $1.12 \mathrm{~kg} / \mathrm{ha}$ or more of atrazine at Adin Pass were free of annual grasses the fallow year (Table 1). At lower elevations in the sagebrush zone, the atrazine-treated areas would be completely bare in the fallow year, but in the woodland on Adin Mountain the native bindweed (Convolvulus polymorphus) persisted or increased on atrazine-treated areas. Turkey mullein (Eremocarpus setigerus) became established late in summer (Table 1). Atrazine applied at 1.68 and $2.24 \mathrm{~kg} /$ ha reduced the perennialgrass stand. It is difficult to predict the influence of atrazine on established perennial grasses. There is no apparent physiological selectivity between annual and pcrennial grasses involved, but the relatively insoluble atrazine may not be leached to the deeper rooting zone of the perennial grasses. Various combinations and interactions of soil, moisture, slope, and species of perennial grass may result in no injury or incomplete mortality from application of $1.12 \mathrm{~kg} / \mathrm{ha}$ of atrazine. Orchardgrass (Dactylis glomerata) was among several exotic perennial grasses previously established on the burn at Adin Pass. Plants of this species survived on plots sprayed with $2.24 \mathrm{~kg} / \mathrm{ha}$ of atrazine.

The biomass of vegetation the fallow year was reduced from 520 to $70 \mathrm{~kg} / \mathrm{ha}$ by applying $1.68 \mathrm{~kg} / \mathrm{ha}$ of atrazine (Table 1). This reduction conserved moisture and nitrate, providing a desirable environment for the establishment of perennial wheatgrasses the following year (Evans et al., 1969; Eckert et al., 1970). Three years after spraying atrazine at 1.12 or $1.68 \mathrm{~kg} / \mathrm{ha}$, and 2 years after the areas were seeded, perennial-grass production was 13 to 16 times as high on sprayed plots as on control areas (Table 2). Medusahead reinvaded the intermediate wheatgrass stands, but this annual grass was greatly suppressed by the established perennial grasses.

When a high rate of atrazine $(2.24 \mathrm{~kg} / \mathrm{ha})$ was applied, too much herbicide activity persisted after 1 year of fallow to allow establishment of wheatgrasses (Evans et al., 1969). However, a period of more than 1 year of herbicidal activity
Table 2. Herbage yield (kg/ha) in 1970 of medusahead, perennial grasses, and forbs on plots at Adin Pass 2 years after seeding and 3 years after atrazine application. ${ }^{\mathrm{a}}$

\begin{tabular}{lcccc}
\hline \hline & \multicolumn{4}{c}{ Herbage yield } \\
\cline { 2 - 5 } $\begin{array}{c}\text { Atrazine } \\
(\mathrm{kg} / \mathrm{ha})\end{array}$ & Medusahead & $\begin{array}{l}\text { Perennial } \\
\text { grasses }\end{array}$ & Forbs & Total \\
\hline Control & $360 \mathrm{a}$ & $40 \mathrm{c}$ & $30 \mathrm{~b}$ & $430 \mathrm{c}$ \\
0.56 & $400 \mathrm{a}$ & $20 \mathrm{c}$ & $80 \mathrm{a}$ & $500 \mathrm{~b}$ \\
1.12 & $30 \mathrm{~b}$ & $520 \mathrm{a}$ & $10 \mathrm{c}$ & $560 \mathrm{~b}$ \\
1.68 & $20 \mathrm{~b}$ & $640 \mathrm{a}$ & $10 \mathrm{c}$ & $670 \mathrm{a}$ \\
2.24 & $10 \mathrm{~b}$ & $140 \mathrm{~b}$ & $60 \mathrm{a}$ & $210 \mathrm{a}$ \\
\hline
\end{tabular}

${ }^{a}$ Means followed by the same letter are not significantly different at the $\mathbf{0 . 0 5}$ level of probability as determined by Duncan's multiple-range test. All comparisons are made vertically.

Table 3. Survival (\%) and height (cm) of pine and bitterbrush seedlings and number (per $36 \mathrm{~m}^{2}$ ) of naturally established bitterbrush seedlings on Adin Pass in 1972. Atrazine applied in 1966; trees and bitterbrush transplanted in $1967 .^{\mathrm{a}}$

\begin{tabular}{lllcc}
\hline \hline $\begin{array}{c}\text { Atrazine } \\
(\mathrm{kg} / \mathrm{ha})\end{array}$ & $\begin{array}{c}\text { Pine seed- } \\
\text { ling height }\end{array}$ & Pine & Bitterbrush & $\begin{array}{c}\text { Density of } \\
\text { naturally } \\
\text { established } \\
\text { bitterbrush } \\
\text { seedlings }\end{array}$ \\
\hline Control & $30 \mathrm{c}$ & $8 \mathrm{~b}$ & $9 \mathrm{~b}$ & 0 \\
0.56 & $40 \mathrm{bc}$ & $18 \mathrm{~b}$ & $0 \mathrm{~b}$ & 0 \\
1.12 & $60 \mathrm{~b}$ & $90 \mathrm{a}$ & $96 \mathrm{a}$ & 2 \\
1.68 & $65 \mathrm{ab}$ & $88 \mathrm{a}$ & $86 \mathrm{a}$ & 3 \\
2.24 & $75 \mathrm{a}$ & $96 \mathrm{a}$ & $98 \mathrm{a}$ & 6 \\
\hline
\end{tabular}

${ }^{\mathrm{a}}$ Means followed by the same letter are not significantly different at the $\mathbf{0 . 0 5}$ level of probability as determined by Duncan's multiple range test. All comparisons are made vertically.

$b_{\text {No significant differences existed among densities of bitterbrush }}$ seedlings.

Table 4. Percentage survival and mean height $(\mathrm{cm})$ of pine seedlings at Baggett Gulch 2 years after planting. ${ }^{a}$

\begin{tabular}{cccccc}
\hline \hline \multirow{2}{*}{$\begin{array}{c}\text { Atra zine } \\
(\mathrm{kg} / \mathrm{ha})\end{array}$} & \multicolumn{2}{c}{$\begin{array}{c}\text { Spring application } \\
\text { of atrazine }\end{array}$} & & \multicolumn{2}{c}{$\begin{array}{c}\text { Fall application } \\
\text { of atrazine }\end{array}$} \\
\cline { 2 - 3 } \cline { 5 - 6 } \cline { 5 - 6 } & Survival $^{\mathrm{b}}$ & Height & & Survival & Height \\
\hline Control & 20 & $10 \mathrm{~b}$ & & $20 \mathrm{~b}$ & $18 \mathrm{c}$ \\
1.12 & 18 & $18 \mathrm{~b}$ & & $80 \mathrm{a}$ & $43 \mathrm{~b}$ \\
2.24 & 30 & $18 \mathrm{~b}$ & & $90 \mathrm{a}$ & $40 \mathrm{~b}$ \\
4.48 & 24 & $20 \mathrm{~b}$ & & $90 \mathrm{a}$ & $56 \mathrm{~b}$ \\
8.96 & 40 & $45 \mathrm{a}$ & & $95 \mathrm{a}$ & $78 \mathrm{a}$ \\
\hline
\end{tabular}

aeans followed by the same letter are not significantly different at the $\mathbf{0 . 0 5}$ level of probability as determined by Duncan's multiple range test. All comparisons are made vertically.

$b_{\text {No significant differences existed among survival percentages of pine }}$ seedlings treated with spring-applied atrazine.

may be an advantage for growing trees or browse species.

Establishment of pine or bitterbrush transplants was greatly increased by applications of $1.12 \mathrm{~kg} / \mathrm{ha}$ of atrazine (Table 3). We failed to establish bitterbrush transplants on plots sprayed with $0.56 \mathrm{~kg} / \mathrm{ha}$ of atrazine or on check plots. Applications of atrazine greater than $1.12 \mathrm{~kg} / \mathrm{ha}$ did not significantly increase survival of trees or bitterbrush. Almost all mortality of pine and bitterbrush seedlings on control or $0.56 \mathrm{~kg} / \mathrm{ha}$ of atrazine treatments occurred during the first summer after transplanting. Transplants on plots with higher rates of atrazine either disappeared apparently from rodent activity (Crouch, 1971), or were heavily browsed by deer.

The high rates of atrazine (1.68 and $2.24 \mathrm{~kg} / \mathrm{ha})$ did not increase survival of pine or bitterbrush transplants, but five years after establishment, trees growing on plots that had been sprayed with $2.24 \mathrm{~kg} / \mathrm{ha}$ of atrazine were significantly taller than those on check plots or on plots sprayed with $1.12 \mathrm{~kg} / \mathrm{ha}$ 
Table 5. Frequency (\%) and cover (\%) of herbaceous vegetation in 1972 in relation to atrazine application of October, 1968, at Baggett Gulch.

\begin{tabular}{|c|c|c|c|c|c|c|c|}
\hline \multirow[b]{2}{*}{$\begin{array}{l}\text { Atrazine } \\
(\mathrm{kg} / \mathrm{ha})\end{array}$} & \multicolumn{6}{|c|}{ Percent frequency } & \multirow[b]{2}{*}{$\begin{array}{l}\text { Herbage } \\
\text { cover }\end{array}$} \\
\hline & $\begin{array}{l}\text { Downy } \\
\text { brome }\end{array}$ & $\begin{array}{c}\text { Mountain } \\
\text { brome }\end{array}$ & $\begin{array}{c}\text { Columbia } \\
\text { needlegrass }\end{array}$ & $\begin{array}{l}\text { Bluebunch } \\
\text { whea tgrass }\end{array}$ & Dogbane & Goldenrod & \\
\hline Control & 35 & 40 & 5 & 10 & 5 & 5 & 30 \\
\hline 1.12 & 75 & 10 & 2 & 3 & 7 & 3 & 28 \\
\hline 8.96 & 3 & 2 & 5 & 1 & 84 & 5 & 8 \\
\hline
\end{tabular}

of atrazine (Table 3).

There was a great deal of caching of seeds by rodents in the atrazine-treated areas. We have noted this activity before (LaTourrette et al., 1971), especially in regard to caching of downy brome seeds. As a result of rodents caching bitterbrush seeds in atrazine-treated areas, many more plants became established than were transplanted (Table 3). Also, seedlings of western juniper were found in atrazine-treated plots. Rodent caching is a significant factor in the establishment of bitterbrush in central Oregon (Sherman and Chilcote, 1972). The pattern of cache placement is strongly influenced by the presence of litter. As litter accumulates, desirable litter-free sites are less abundant, and bitterbrush populations decline. The application of atrazine at $1.12 \mathrm{~kg} / \mathrm{ha}$ or higher rates results in a loss of herbaceous litter and a friable soil structure (Evans and Young, 1970 and 1972), which apparently create a desirable caching site for rodents.

On vertisol-clay soils such as are found at Adin Pass, considerable downslope movement of atrazinc occurs during the winter. This movement is apparently a function of clay particles that move with atrazine attached. Erosional patterns caused by atrazine activity were particularly desirable sites for rodent seed caching.

Comparison of atrazine and a simazine at the same rates at Adin Pass did not reveal enough differences between results of the two herbicides to justify detailed presentation. Evans et al. (1969) provide details of comparisons of these herbicides under conditions of rangelands.

We did not seed intermediate wheatgrass in areas treated with herbicides in 1968 (active fallow during 1969). Tree and bitterbrush establishment in relation to rate of atrazine was similar to that already presented (Table 3). By 1972, these unseeded plots have been reinvaded by dense stands of medusahead. We do not know if this reinvasion will have a long-term effect on tree or brush growth, but it greatly increases the chance of reburning.

\section{Baggett Gulch}

The results of application of atrazine at Baggett Gulch were very similar to those reported for Adin Pass, although soil and exposure were different, and downy brome dominated instead of medusahead.

Fall application of $1.12 \mathrm{~kg} / \mathrm{ha}$ of atrazine greatly improved the establishment of spring-transplanted pine seedlings (Table 4). Spring applications of atrazine after the seedlings were transplanted did not result in markedly increascd survival. There probably was not enough late-spring precipitation to activate the herbicide after spring application (Evans et al., 1969). Vigor of transplants was increased with spring application of atrazine at $8.96 \mathrm{~kg} / \mathrm{ha}$ (Table 4). This resulted from control of downy brome and suppression of competition in subsequent years from residual herbicidal activity. The plots receiving $8.96 \mathrm{~kg} / \mathrm{ha}$ of atrazine in October, 1968 were largely bare of vegetation in 1972 (Table 5). Little or no downy brome had reinvaded the area. The sparse ground cover $(8 \%)$ was composed of dogbane (Apocynum androsaemifolium) and western goldenrod (Solidago californica), and a few remnant perennial grasses (Table 5). The plots receiving lower rates of atrazine were reinvaded by downy brome or plants representing lower successional stages by 1972 . The areas treated with $1.12 \mathrm{~kg} / \mathrm{ha}$ of atrazine had a higher frequency of downy brome and a lower frequency of perennial grasses than was measured on the control areas.

We did not transplant bitterbrush to the Bagget Creek plots, nor did we observe any naturally-establishing bitterbrush seedlings in atrazine-treated areas. However, there is no bitterbrush in the extensive burned areas around the experimental site. We did not observe downslope movement of atrazine at this location with a silt loam surface soil.

\section{Discussion}

The vegetation manipulations outlined in this study are unnecessary if prompt rehabilitation of burned areas is accomplished. Supposedly, through grazing management, perennial grasses established after burning can be harvested without undue damage to conifer regeneration. Where woodland burns are left unseeded, either through inaction or fear of competition with conifers, annual-grass invasion is virtually assured.

Once annual grasses have invaded, the procedures of this study apply. The land manager must decide, weighing site potential and desired use, if he wants to establish a stable perennial grass-shrub-conifer community or to attempt to encourage a maximum rate of conifer growth with higher and perhaps repeated applications of atrazine.

The use of atrazine has valid application in many areas of reforestation. In this investigation, we are dealing with sites of very low potential for ponderosa pine growth. This underscores the importance of a balanced revegetation program, with perennial grasses and shrubs in addition to conifers.

\section{Literature Cited}

Crouch, G. L. 1971. Susceptibility of ponderosa, Jeffrey, and lodgepole pines to pocket gophers. Northwest Sci. 45:252-255.

Eckert, R. E., Jr., G. J. Klomp, J. A. Young, and R. A. Evans. 1970. Nitrate-nitrogen status of fallowed rangeland soils. J. Range Manage. 23:445-447.

Evans, R. A., and R. M. Love. 1957. The step-point method of sampling - a practical tool in range research. J. Range Manage. 10:208-212.

Evans, R. A., R. E. Eckert, Jr., B. L. Kay, and J. A. Young. 1969. Downy brome control by soil-active herbicides for revegetation of rangelands. Weed Sci. 17:166-169.

Evans, R. A., and J. A. Young. 1970. Plant litter and establishment of alien weed species in rangeland communities. Weed Sci. 18:697-703.

Evans, R. A., and J. A. Young. 1972. Microsite requirements for establishment of annual rangeland weeds. Weed Sci. 20:350-356.

LaTourrette, J. E., J. A. Young, and R. A. Evans. 1971. Seed dispersal in relation to rodent activities in seral big sagebrush communities. J. Range Manage. 24:118-120.

Sherman, R. J., and W. W. Chilcote. 1972. Spatial and chronological patterns of Purshia tridentata as influenced by Pinus ponderosa. Ecology 53:294-298.

Young, J. A., and R. A. Evans. 1970. Invasion of medusahead into the Great Basin. Weed Sci. 18:89-97. 